\title{
Development of domestic brands in the fashion market
}

\author{
Anastasiya Melnikova* \\ G.V. Plekhanov REU, Stremyanny Lane, 36, 117997 Moscow, Russian Federation
}

\begin{abstract}
This article deals with the analysis of the development of domestic brands in the fashion market. At the moment, foreign brands prevail in this market. However, based on the experience of a number of countries, we can say that the fashion industry can make a significant contribution to a country's GDP. This research examines the development of brands in terms of their relevance and recognition among potential consumers. As a result, conclusions are drawn about consumer preferences and the most effective methods of taking on the market.
\end{abstract}

\section{Introduction}

The domestic fashion market is now saturated with foreign brands. According to the report of the Russian Union of Entrepreneurs of Textile and Light Industry, at the end of 2017, the share of Russian goods in the total volume of light industry products in the domestic market is $20 \%$ [1] $10 \%$ of which are designer clothes [2]. The strategy for the development of the Russian light industry until 2025 includes support for national brands and the creation of fashion clusters with the subsequent goal of bringing domestic brands to the world market.

The Strategic Initiatives Agency (SIA), together with the National Chamber of Fashion, under the state support, is planning a number of measures to support Russian manufacturers in the fashion industry with the ultimate goal of increasing the share of Russian companies in the domestic market of clothing, footwear, and accessories by about $50 \%$ by 2035 . According to preliminary forecasts, 10 thousand fashion companies with a turnover of more than $\$ 1$ million per year each can already operate by this time in Russia, and export at least $30 \%$ of their products $[3,4]$.

If we consider the attractiveness of this market in terms of the demand for domestic goods, then according to a study by the Association of Internet Trade Companies (AITC) jointly with KupiVIP and Google, 96.7\% of Russians buy Russian brands. About half of them do it consciously, as there are worthy brands in Russia (50.8\%). Another point to note is that the interest of buyers in Russian-made designer brands is increasing at a significant pace. The number of searches for designer clothing in 2016 increased by $33.8 \%$ compared to 2015 . In the first quarter of 2017 , interest increased by $27 \%$ compared to the first quarter of 2016. At the same time, the total number of requests other than in the brand category in the first quarter of 2017 dropped by $15 \%$ in relation to the first quarter of 2016 [5].

\footnotetext{
${ }^{*}$ Corresponding author: anastasija hrom@,bk.ru
} 
Thus, the current domestic fashion market shows significant growth; in addition, the growth of interest from consumers, as well as active measures of support from the state, are important.

\section{Material and Methods}

The methodological basis of this study is general scientific methods of researching economic activity, marketing and statistical methods of analysis (segmentation, correlation analysis), as well as various methods of collecting information (interviewing, expert assessments, surveys, questionnaires).

The experimental base of the study was the results of special targeted studies (surveys, questionnaires, focus groups, in-depth interviews), analytical reports of domestic and foreign consulting companies, materials of scientific conferences, Internet sources.

The research object is the design of domestic fashion brands. The subject of the research is the development of designer domestic fashion brands in the Russian fashion market.

A designer brand is "an individualized name, term, sign, symbol, and design, as well as their combinations used to identify seasonal fashion products that have an attributed creator (designer) and to differentiate them from competitors' fashion products [6].

Domestic designer goods have the following distinctive features from foreign ones. Domestic brands belong to the so-called "new luxury" - even the oldest Russian brands are younger, for example, than the European brands "with history". Prices also differ: Russian brands have a lower pricing policy compared to foreign brands of the same category. Also, the level of recognition of domestic brands is generally lower, even among the population of Russia. As a rule, the circulation of a Russian brand is much less than foreign ones.

All these features of domestic designer brands have an impact on consumer demand.

This research focuses on the analysis of brand development in terms of the popularity of these brands among consumers. For this purpose, the author's segmentation of consumers of designer domestic fashion brands has been developed.

The current consumer segmentation, both in the international and domestic markets, does not separately consider a special segment of consumers - the clients of Russian designer brands. The segmentation proposed by the author was based on interviews with the owners of well-known domestic brands and stylists, as well as a review of open sources [10].

On their basis, the following consumer segments were identified:

- Show business stars, celebrities;

- Other secular representatives;

- Top-level office workers;

- Representatives of creative professions;

- "Golden youth".

- We shall consider each of the listed segments now in more detail.

Show business stars, celebrities, well-known bloggers, as a rule, get branded outfits for free, however, this segment is very important as shaping fashion and consumption patterns for other consumers (trendsetters).

Other, less well-known representatives of the secular society, and therefore not trendsetters, more often choose domestic brands for making their mark, as the quality of Russian brands corresponds to more expensive foreign ones at a significantly lower price [7]. In addition, Russian brands are "unhackneyed" and makes one standing out from the crowd.

Top-level office workers. Consumers are mainly women of major posts in mediumsized companies, aged 35-45, who value good quality clothing that matches their dress code. Those who want to look expensive at the right price. 
Representatives of creative professions. They appreciate the unusual design and authenticity of domestic brands.

"Golden youth". Age limits: from 17 to 25 years old; students of leading universities or recent graduates. By age category, the "golden youth" belongs to generation X. Among this generation, Russian brands are quite popular. Another important characteristic is that they show less commitment to one brand and are always looking for a new one [8].

The next stage is the analysis of brands that refer to the design category and are Russian in terms of brand origin. This analysis was carried out in 2 stages: the first stage included the study of secondary information about brands on the Internet, the second is a survey of the target audience.

At the first stage, by analyzing secondary information, the most famous Russian designers were identified. The following sources were used as secondary information: 1) the average number of requests per month in Yandex over the past 3 years (information source: wordstat.yandex.ru), 2) the average number of visits per month to the brand's website (using megaindex.com), 3) the number of subscribers on social Internet networks such as Instagram and Facebook. This stage of the research was carried out from August 2017 to January 2018. The base of designers formed in this way was further used in the research.

To collect primary information, a questionnaire has been developed, presented at: https://ru.surveymonkey.com/r/TRD5VRK. The survey involved the target audience and customers of the brand, as well as potential buyers. For this study, the survey was conducted only within one market segment - students of the country's leading universities (Plekhanov Russian University of Economics and Higher School of Economics) aged 18 to 22 , as the most active market participants interested in fashion. The sample consisted of 152 people, including 88 girls and 64 boys. The survey proceeded in 2 stages: the first from April to June 2018, and the second from July to August 2019, using surveymonkey.com.

\section{Results and Discussion}

The answer to the first question "What Russian designer brands/fashion designers seem to you the most popular today?" did not almost need prompting, which means that representatives of the selected segment can name the most popular brands from memory. A similar survey conducted for another study among older respondents showed that the percentage of those who answered from their memory is much lower. This again confirms the higher awareness of Russian fashion brands among representatives of generation X [9].

The most frequently mentioned designers are: Valentin Iudashkin (79\% of answers), Gosha Rubchinskii (75\%), Aleksandr Terekhov (67\%), Alena Akhmadulina and Uliana Sergeenko (33\% each).

The next question asked to assess the awareness of the provided list of brands on a 4point scale, where 0 points - the first time I meet this name, 1 point - I have heard, but I don't know what it produces, 2 points - I have an idea of a brand, 3 points - the brand is well known to me, 4 points - I am a client of this brand. According to the results of answers to this question, brands such as Slava Zaitsev, Valentin Iudashkin, Masha Tsigal, Uliana Sergeenko, Chapurin, Igor Guliaev, Bella Potemkina and Ruban can be attributed to the most recognizable brands. Figure 1 shows a summary bar chart of the response results.

The next stage is a detailed analysis of the marketing activities of popular Russian designers to identify the most effective promotion tools that contribute to brand development.

The peculiarities of the fashion industry make the whole range of marketing communications highly specific. Based on the interviews with designers, the following marketing tools used in the industry were identified: 
1. Participation in Russian/foreign fashion weeks

2. Involvement of Russian/foreign celebrities for promotion purposes

3. Publications in glossy magazines and popular online publications

4. Involvement of bloggers and professional stylists

5. Design and location of the point of sale

6. Cooperation with large on-line and off-line marketplaces

The identified tools were included in a consumer survey to analyze the channel of the obtained information.

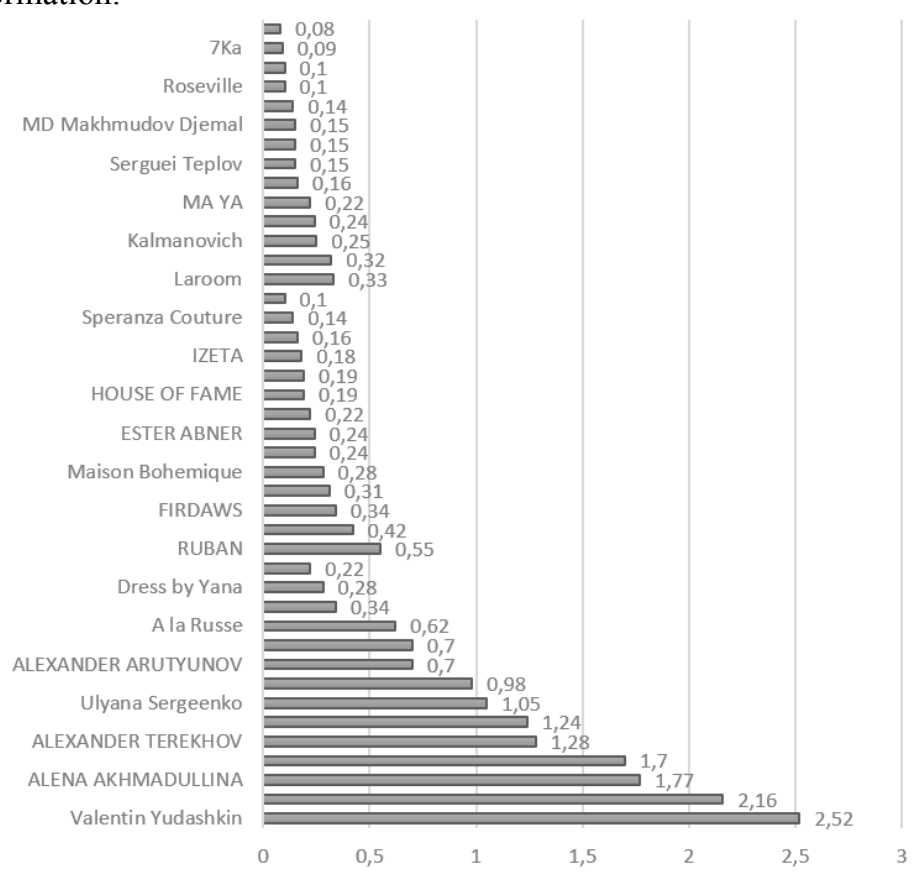

Fig. 1. Awareness of Russian designers

Table 1 shows the results of the answer to the question "What are your sources of information about these brands?"

Table 1. Main sources of consumer information

\begin{tabular}{|l|l|}
\hline Social networks & $59.09 \%$ \\
\hline I found the store of this brand & $46.59 \%$ \\
\hline We saw the clothes of these brands on Russian stars and celebrities & $45.45 \%$ \\
\hline Bloggers & $42.05 \%$ \\
\hline Glossy magazines & $34.09 \%$ \\
\hline Russian fashion weeks & $25.00 \%$ \\
\hline Online versions of magazines & $22.73 \%$ \\
\hline Friends & $18.18 \%$ \\
\hline The brand's products were in the online store where I did the shopping & $17.05 \%$ \\
\hline
\end{tabular}


Table 1. Continued

\begin{tabular}{|l|l|}
\hline Contextual advertising & $11.36 \%$ \\
\hline We saw the clothes of these brands on foreign stars and celebrities & $9.09 \%$ \\
\hline Other (specify) & $7.95 \%$ \\
\hline Foreign fashion weeks & $5.68 \%$ \\
\hline
\end{tabular}

At the next stage of the study, the subjective assessments of the awareness of consumers about brands are used as the level of brand awareness. At this stage, a correlation analysis of the level of recognition of a designer brand with its marketing activity is carried out. To assess marketing activity, the following attributes are identified:

- Number of subscribers in social networks

- The level of involvement of celebrities in advertising

- Number of outlets

- Activity of publications in glossy magazines

- The number of shows in Russia during fashion weeks

Attributes such as the engagement of celebrities and the activity of publications were obtained through expert assessments from 1 to 4, depending on the level of involvement and activity. The rest of the attributes are absolute quantitative indicators. This analysis is carried out only for the most recognizable brands, according to the respondents.

Table 2 presents data for the selected brands.

Table 2. Identification of the group of Russian brands, the most active in communication activities

\begin{tabular}{|c|c|c|c|c|c|}
\hline Brand & $\begin{array}{c}\text { Aware } \\
\text { ness }\end{array}$ & $\begin{array}{c}\text { Shows, } \\
\text { number }\end{array}$ & $\begin{array}{c}\text { Followers, } \\
\text { thousand people }\end{array}$ & $\begin{array}{c}\text { Stores, } \\
\text { number }\end{array}$ & Magazines \\
\hline A laRusse & 0.64 & 1 & 78 & 3 & 4 \\
\hline ALENA AKHMADULLINA & 2.64 & 15 & 486 & 4 & 4 \\
\hline $\begin{array}{c}\text { ALEXANDER } \\
\text { ARUTYUNOV }\end{array}$ & 1.27 & 5 & 156 & 4 & 2 \\
\hline ALEXANDER TEREKHOV & 2.45 & 9 & 342 & 4 & 3 \\
\hline Bella Potemkina & 1.18 & 5 & 543 & 4 & 4 \\
\hline CHAPURIN & 2.00 & 10 & 346 & 3 & 4 \\
\hline DressbyYana & 0.55 & 0 & 64 & 2 & 1 \\
\hline Ulyana Sergeenko & 2.27 & $\mathrm{~W}$ & 315 & 3 & 3 \\
\hline IGOR GULYAEV & 1.09 & 9 & 134 & 4 & 2 \\
\hline Valentin Yudashkin & 2.55 & 24 & 313 & 2 & 3 \\
\hline MASHA TSIGAL & 2.18 & 12 & 261 & 1 & 1 \\
\hline Slava Zaitsev & 2.17 & 30 & 266 & 4 & 3 \\
\hline Vilshenko & 0.27 & 0 & 64 & 2 & 1 \\
\hline YANINA COUTURE & 0.82 & 4 & 43 & 3 & 2 \\
\hline
\end{tabular}

The results of correlation analysis for the four listed attributes are presented in Table 3.

Table 3. Indicators of correlation between brand awareness and selected attributes

\begin{tabular}{|c|c|c|c|}
\hline Shows & $\begin{array}{c}\text { Followers, thousand } \\
\text { people }\end{array}$ & Stores, number & Magazines \\
\hline 0.69 & 0.71 & 0.14 & 0.42 \\
\hline
\end{tabular}




\section{Conclusion}

The conducted research allows us to make the following conclusion.

The share of truly popular Russian designers is small. Almost all recognizable designers have been in the market for over 8 years.

The most effective marketing tools for brand development in the domestic fashion industry market are brand participation in fashion shows and activity on social networks. According to the results of the correlation analysis, the number of stores has practically no effect on awareness, however, consumers singled out the outlet attribute as significant, probably because it is important for them where the store is located or how it looks. This question is open for further analysis.

The analysis of the survey showed that the audience with an income below 70,000 rubles lacks consumers of designer items. The largest number of designers' clients is found among the audience with an average monthly income of 120,000 to 200,000 rubles and higher.

Another important conclusion is the fact that the majority of respondents value the products of Russian designers for their uniqueness, authenticity, and design. However, the lack of brand awareness according to the survey results for $54 \%$ of respondents is a disadvantage. This is due to the desire for conspicuous consumption, characteristic of Russian society. In addition, $37 \%$ of the respondents noted the low quality of goods.

\section{References}

1. I.I. Skorobogatykh, Bulletin of G.V. Plekhanov Russian Economic Academy, 2, 96 (2008)

2. Fashionreport official website, http://www.fashion-report.ru

3. A.V. Melnikova, Actual problems of development and support of entrepreneurship in the fashion industry in Russia, 9(2-1), 117 (2019)

4. Official website of the Russian Union of Entrepreneurs of the Textile and Light Industry, http://www.souzlegprom.ru

5. Official portal "All about advertising, marketing and PR", http://www.advertology.ru

6. A.N. Andreeva, Designer brands in fashion business, 256 (2008)

7. J.F. Engel, R.D. Blackwell, P.W. Miniard, Consumer behavior, 768 (1999)

8. A.V. Melnikova, Economics, entrepreneurship and law, consumer perception of fashion industry products, 10(2), 297 (2020)

9. A.V. Chenchik, Russian entrepreneurship, portrait of the modern consumer of luxury goods, 19(4), 1315 (2018)

10. The study of the demand for sewing services and the production of sewing products, (2017) 